\title{
PERAN WHISTLE BLOWING SYSTEM DALAM MEMODERASI PENERAPAN E-FILLING DAN SANKSI PERPAJAKAN TERHADAP KEPATUHAN WAJIB PAJAK
}

\author{
Mariska Intan Dwi Syafitri \\ Program Studi S1 Akuntansi Fakultas Ekonomi, Universitas Pamulang \\ mariskaintan75@gmail.com \\ Zulfa Rosharlianti \\ Program Studi S1 Akuntansi Fakultas Ekonomi, Universitas Pamulang \\ dosen00876@unpam.ac.id
}

\begin{abstract}
Abstrak: Peran Whistle Blowing System Dalam Memoderasi Penerapan E-Filling Dan Sanksi Perpajakan Terhadap Kepatuhan Wajib Pajak. Penelitian ini bertujuan untuk mengetahui peran Whistle Blowing System dalam Memoderasi penerapan E-Filling dan Sanksi Perpajakan terhadap Kepatuhan Wajib Pajak. Penelitian ini menggunakan metode kuantitatif. Populasi dalam penelitian ini adalah Wajib Pajak Orang Pribadi yang terdaftar di Kantor Pelayanan Pajak Pratama Serpong. Teknik pengambilan sampel dengan random sampling dan penentuan jumlah sampel menggunakan rumus slovin dan diperoleh 108 responden. Teknik pengumpulan data menggunakan kuesioner yang telah diuji validitas dan reliabilitasnya. Teknik analisis data menggunakan regresi berganda dan analisis regresi moderasi. Hasil penelitian ini menunjukkan bahwa penerapan e-filing dan sanksi perpajakan berpengaruh positif dan signifikan terhadap kepatuhan wajib pajak. Sedangkan Whistle Blowing mampu memoderasi pengaruh penerapan $e$-filing dan sanksi perpajakan terhadap kepatuhan wajib pajak.
\end{abstract}

Kata kunci: Penerapan e-Filing, Sanksi Pajak, Kepatuhan Wajib Pajak, Whistle Blowing

Abstract: The Role of the Whistle Blowing System in Moderating the Application of EFilling and Tax Sanctions Against Taxpayer Compliance. This study aims to determine the role of the Whistle Blowing System in Moderating the application of E-Filling and Tax Sanctions on Taxpayer Compliance. This research uses quantitative methods. The population in this study is the Individual Taxpayer who is registered at the Serpong Tax Service Office. The sampling technique was random sampling and the determination of the number of samples using the Slovin formula and obtained 108 respondents. Data collection techniques using a questionnaire that has been tested for validity and reliability. Data analysis techniques using multiple regression and moderation regression analysis. The results of this study indicate that the application of e-filing and tax sanctions have a positive and significant effect on taxpayer compliance. Whereas Whistle Blowing is able to moderate the effect of e-filing and taxation sanctions on taxpayer compliance.

Keywords: The role of e-Filing, Tax Sanctions, Taxpayer Compliance, Whistle Blowing

\section{PENDAHULUAN}

Modernisasi sistem pelaporan pajak dilakukan sejak tanggal 24 januari 2005. Aplikasi e-SPT atau disebut dengan Elektronik SPT adalah aplikasi yang dibuat oleh Direktorat Jenderal Pajak dan digunakan oleh wajib pajak untuk kemudahan dalam menyampaikan SPT. Aplikasi e-Filling adalah suatu cara penyampaian SPT atau Pemberitahuan Perpanjangan SPT Tahunan yang dilakukan secara online dan real time melalui Penyedia Jasa Aplikasi atau Application Service Provider (ASP). Di sini terlihat perbedaan antara $e-S P T$ dan $e$ - 


\section{Nominal: Barometer Riset Akuntansi dan Manajemen \\ P-ISSN: 2303-2065 E-ISSN: 2502-5430 \\ Volume 9 No 2 (2020)}

Filling. E-SPT adalah medianya sedangkan $e$-Filling adalah cara penyampaiannya.

Meskipun e-Filing pajak sudah tidak asing terdengar, namun masih ada sebagian orang yang belum tahu apa itu e-Filing. EFiling atau lapor pajak online adalah penyampaian Surat Pemberitahuan (SPT) melalui saluran pelaporan pajak elektronik atau online yang telah ditetapkan oleh Direktorat Jenderal Pajak (DJP) pada Peraturan DJP Nomor PER-03/PJ/2015. Dengan adanya e-Filing atau lapor pajak online, diharapkan dapat mengurangi antrian di KPP yang selalu diramaikan oleh masyarakat yang ingin menunaikan kewajiban mereka untuk mengurus perpajakan. Latar belakang diberlakukannya e-Filing ini merupakan suatu transformasi terhadap sistem administrasi perpajakan di Indonesia. Jika sebelumnya proses pelaporan pajak dilakukan dengan cara Wajib Pajak harus selalu datang ke KPP, kini tidak lagi.

Adapun pentingnya penggunaan $e$ Filling pajak antara lain: Lapor SPT dapat dilakukan dengan cepat karena melalui jaringan internet yang proses penerimaan datanya dilakukan secara online dan real time, E-Filing pajak dapat dilakukan kapan dan di mana saja selama Wajib Pajak terhubung dengan internet, E-Filing merupakan sebuah aplikasi yang mudah digunakan (user-friendly). Setiap Wajib Pajak hanya perlu masuk ke website DJP
Online atau ASP resmi, seperti Klikpajak. Penggunaan $e$-Filing terbukti tidak ribet. Setiap Wajib Pajak tidak perlu melakukan instalasi aplikasi apapun jika melakukan $e$ Filing melalui website DJP atau menggunakan aplikasi pajak dari ASP resmi lainnya, Menggunakan e-Filing tentu saja dapat menghemat biaya. Artinya, setiap Wajib Pajak tidak perlu mengeluarkan biaya untuk pergi ke KPP dan dengan adanya layanan ini, maka Wajib Pajak diharapkan dapat lebih mudah dalam lapor pajak. Dan tentunya harus lebih taat lagi dalam membayar pajak. Karena penggunaan $e$ Filing tanpa dipungut biaya apapun alias gratis.

Namun, faktanya masih banyak Wajib Pajak yang belum mengerti sepenuhnya cara melaporkan SPT secara elektronik, padahal banyak manfaat yang didapatkan apabila menggunakan $e$-Filling. Masih ada beberapa Wajib Pajak yang tidak sepenuhnya memahami tentang peraturan perpajakan akan berdampak pada penerimaan pajak di Indonesia.

Menurut data Ditjen Pajak Kemenkeu tahun 2018 mencatat, jumlah wajib pajak (WP) yang terdaftar wajib lapor SPT sebanyak 17.653.963 dengan rincian, WP badan 1.452.428, WP OP non karyawan 2.452.652, dan WP OP karyawan 13.748.883 (Sumber: https://finance.detik.com). 
Nominal: Barometer Riset Akuntansi dan Manajemen

P-ISSN: 2303-2065 E-ISSN: 2502-5430

Volume 9 No 2 (2020)

Direktorat Jenderal Pajak (DJP) Kementerian Keuangan (Kemenkeu) sudah menerima laporan 10.589 .648 Surat Pemberitahuan (SPT) Tahunan 2017 hingga 31 Maret 2018. Angka tersebut naik 14,01\% dibandingkan periode tahun lalu yang sekitar 9.288.386. Dari total hampir 10,6 juta SPT tersebut, 244.084 di antaranya merupakan SPT badan, 993.754 merupakan SPT orang pribadi (OP) non karyawan, dan 9.351.810 merupakan SPT OP karyawan. Untuk rasio kepatuhan Wajib Oajak karyawan, tercatat sebesar 68 persen atau meningkat dibanding 2017 sebesar 61,9 persen serta non-karyawan sebesar 40,5 persen yang meningkat dibanding tahun 2017 sebesar 38,8 persen. Mengenai pergeseran tata cara WP Orang Pribadi melaporkan SPT mereka, didapati pertumbuhan pelaporan SPT secara elektronik sebesar 21,6 persen. Cara elektronik yang dimaksud dalam hal ini adalah e-Filling dan e-form, tidak termasuk dengan metode e-SPT. (Sumber: https://ekonomi.kompas.com).

Salah satu yang menjadi penyebab rendahnya tax ratio tersebut adalah rendahnya tingkat kepatuhan wajib pajak, dimana dalam melaksanakan sistem perpajakan di Indonesia yang menganut self assessment system sangat tergantung kepada kepatuhan dari wajib pajak untuk memenuhi hak dan kewajiban sesuai dengan Undang- undang baik segi formal maupun materialnya (Siringoringo, 2015).

Selain modernisasi administrasi dalam perpajakan salah satu kebijakan pemerintah dalam upaya untuk meningkatkan kepatuhan perpajakan adalah diberikannya sanksi bagi wajib pajak yang tidak memenuhi kewajiban perpajakan sesuai dengan perundangundangan yang berlaku. Sanksi pajak juga memegang peran penting dalam meningkatkan kepatuhan wajib pajak. Dengan adanya sanksi perpajakan diharapkan wajib pajak semakin patuh dalam memenuhi kewajiban perpajakannya.

Sanksi perpajakan merupakan alat pencegah (preventif) agar wajib pajak tidak melanggar norma. Pengenaan sanksi perpajakan diberlakukan untuk menciptakan kepatuhan wajib pajak dalam melaksanakan kewajiban perpajakannya. Sanksi-sanksi dalam perpajakan terdiri atas sanksi administrasi yang meliputi sanksi berupa denda, sanksi berupa bunga, sanksi berupa kenaikan, serta sanksi pidana perpajakan yang meliputi sanksi yang bersifat pelanggaran dan sanksi pidana yang bersifat kejahatan (Siamena et al., 2017)

Menurut Mardiasmo, (2018) sanksi perpajakan merupakan jaminan bahwa peraturan perundang-undangan perpajakan (norma perpajakan) akan dituruti/ditaati/dipatuhi. Dengan demikian, diharapkan diharapkan agar peraturan 


\section{Nominal: Barometer Riset Akuntansi dan Manajemen \\ P-ISSN: 2303-2065 E-ISSN: 2502-5430 \\ Volume 9 No 2 (2020)}

perpajakan dipatuhi oleh para wajib pajak. Wajib pajak akan memenuhi kewajiban perpajakan bila memandang bahwa sanksi perpajakan akan lebih banyak merugikannya. Mangoting \& Jotopurnomo, (2013) menyatakan bahwa sanksi perpajakan berpengaruh positif terhadap kepatuhan wajib pajak. Hal ini diperkuat oleh Ngadiman \& Huslin, (2017) bahwa sanksi perpajakan berpengaruh positif terhadap kepatuhan wajib pajak. Namun berbeda dengan hasil penelitian Ningsih dan Rahayu, (2013) bahwa sanksi perpajakan tidak berpengaruh positif terhadap kepatuhan wajib pajak. Dapat disimpulkan bahwa sanksi perpajakan masih belum dapat sepenuhnya membuat wajib pajak patuh dalam melaksanakan kewajiban perpajakannya. Sehingga hal tersebut memicu antusias peneliti untuk meneliti variabel sanksi perpajakan tersebut.

Selain modernisasi system pelaporan pajak dan sanksi perpajakan transparasi juga menjadi salah satu pendorong dalam meningkatkan kepatuhan wajib pajak. Transparansi pengelolaan pajak yang dilakukan di segala bidang, baik bidang administrasi maupun pengelolaan penggunaan dana yang bersumber dari pendapatan pajak tersebut, karena transparansi akan mempengaruhi tingkat kepercayaan wajib pajak dalam hal pembayaran pajak (Siringoringo, 2015).
Transparansi sangat diperlukan dalam hal keuangan, seperti halnya didalam sektor pajak. Maka dari itu untuk mendorong tingkat transparansi maka perlu adanya pengawasan yang baik, salah satunya dengan menerapkan whistle blowing system yang mulai diterapkan pada tanggal 19 Agustus 2011 dengan dikeluarkannya Surat Edaran Direktorat Jenderal pajak Nomor SE - 11 / PJ / 2011 tentang kewajiban melaporkan pelanggaran dan penanganan pelaporan pelanggaran (whistleblowing) di lingkungan Direktorat Jenderal Pajak (www.pajak.go.id).

Whistleblowing system adalah aplikasi yang disediakan oleh Kementerian Keuangan bagi anda yang memiliki informasi dan ingin melaporkan suatu perbuatan berindikasi pelanggaran yang terjadi di lingkungan Kementerian Keuangan Republik Indonesia (www.wise.kemenkeu.go.id). Dimaksudkan untuk membangun kembali public trust terhapat DJP dan mengajak seluruh pegawai DJP untuk mengubah budaya permisif menjadi budaya korektif yang berarti tidak akan pernah mentolelir adanya pelanggaran dengan cara melaporkannya ke saluran pengaduan yang telah disediakan (Siringoringo, 2015).

\section{KAJIAN LITERATUR}

Sistem E-Filling adalah sebuah sistem administrasi yang digunakan untuk 


\section{Nominal: Barometer Riset Akuntansi dan Manajemen}

P-ISSN: 2303-2065 E-ISSN: 2502-5430

Volume 9 No 2 (2020)

menyampaikan SPT secara elektronik. Sistem ini adalah salah satu inovasi yang dilakukan oleh Direktorat Jenderal Pajak agar Wajib Pajak dapat melaporkan SPT lebih cepat dan kapan saja. Manfaat adalah tingkatan dimana seseorang berfikir bahwa menggunakan suatu sistem akan meningkatkan kinerjanya. Jika Wajib Pajak memandang bahwa sistem E-Filling ini memberikan manfaat bagi dirinya, hal ini akan membentuk sebuah sikap positif dari Wajib Pajak yang selanjutnya akan meningkatkan Kepatuhan Wajib Pajak Orang Pribadi dalam melaporkan SPT. Sebaliknya jika Wajib Pajak memandang bahwa sistem e-filling ini tidak memberikan manfaat bagi dirinya, hal ini akan membentuk sikap negatif dari Wajib Pajak yang selanjutnya tidak akan meningkatkan Kepatuhan Wajib Pajak dalam melaporkan SPT.

Complience theory menjelaskan suatu kondisi dimana seseorang taat terhadap perintah atau aturan yang diberikan. Kepatuhan Wajib Pajak merupakan perilaku yang didasarkan pada kesadaran seorang Wajib Pajak terhadap kewajiban perpajakannya dengan tepat berlandaskan pada peraturan perundang-undangan yang diterapkan. Salah satu cara yang dilakukan oleh DJP adalah dengan melakukan reformasi modernisasi sistem administrasi perpajakan berupa perbaikan pelayanan bagi Wajib Pajak melalui pelayanan yang berbasis e-system seperti e-registration, e-filing, eSPT, dan e-billing.

Penelitian terdahulu yang dilakukan oleh Jayanti, (2017), menunjukan hasil bahwa penerapan e-filing memiliki pengaruh positif yang kuat dalam mempengaruhi hubungan terhadap kepatuhan wajib pajak orang pribadi dalam melaporkan pajak. Hal tersebut disebabkan karena semakin mudah dan efisien Wajib Pajak dalam melaporkan SPT maka akan meningkatkan kepatuhan dalam memenuhi kewajiban perpajakannya.

$\begin{array}{clcr}\mathrm{H}_{1}: & \begin{array}{l}\text { Penerapan } \\ \text { berpengaruh }\end{array} & \text { E-Filling } & \text { diduga } \\ & \text { positif } & \text { terhadap }\end{array}$

Kepatuhan Wajib Pajak Orang Pribadi dalam Melaporkan Pajak.

Theory of Planned behavior menjelaskan niat untuk melakukan suatu tindakan, dipengaruhi oleh tiga faktor diantaranya keyakinan seseorang pada hasil dan evaluasi dari perilakunya, keyakinan akan harapan normatif, dan keinginan untuk mencapainya dan keyakinan akan adanya hal yang mampu menghambat perilakunya.

Dengan adanya sanksi pajak yang dibuat untuk mendukung agar wajib pajak memenuhi peraturan perpajakan yang berlaku. Kepatuhan formal wajib pajak akan ditentukan berdasarkan persepsi wajib pajak tentang seberapa kuat sanksi pajak dapat mendukung perilaku wajib pajak dalam memenuhi kewajiban perpajakan. 


\section{Nominal: Barometer Riset Akuntansi dan Manajemen}

P-ISSN: 2303-2065 E-ISSN: 2502-5430

Volume 9 No 2 (2020)

Menurut Ngadiman dan Huslin, (2017) sanksi pajak mempunyai pengaruh yang signifikan terhadap kepatuhan wajib pajak. Menurut Suyadi dan Sunarti, (2016) sanksi pajak mempunyai pengaruh dan signifikan terhadap kepatuhan wajib pajak. Hal tersebut disebabkan karena dengan adanya sanksi perpajakan maka Wajib Pajak akan semakin dirugikan jika tidak taat dalam melaksanakan kewajiban perpajakannya sehingga sanksi pajak dapat mendorong Wajib Pajak dalam meningkatkan kepatuhan perpajakan dalam menyampaikan SPT.

$\mathrm{H}_{2}$ : Sanksi Pajak diduga berpengaruh positif terhadap Kepatuhan Wajib Pajak Orang Pribadi dalam Melaporkan Pajak.

Sistem e-filing merupakan sebuah sistem administrasi yang digunakan untuk menyampaikan SPT secara elektronik. Sistem ini menjadi salah satu inovasi yang dilakukan oleh Derektorat Jenderal Pajak agar waib pajak dapat melaporkan SPT lebih cepat dan kapan saja (Agustiningsih \& Isroah, 2016). Wajib pajak akan memandang dengan adanya sistem e-filing penyampaian SPT akan lebih efektif dan efisien sehingga dapat meningkatkan kepatuhan wajib pajak dalam menyampaikan SPT.

Control beliefs dalam theory of planned behavior (TPB) menyatakan bahwa terdapat faktor yang dapat menjadi hambatan dalam perilaku yang dilakukan individu. Dalam hal ini sanksi perpajakan adalah faktor yang mampu mendorong wajib pajak untum memenuhi kewajiban perpajakan. Wajib pajak akan menyadari bahwa dengan adanya sanksi pajak akan menambah beban yang akan dikeluarkan, maka hal tersebut akan meningkatkan kepatuhan wajib pajak dalam memenuhi kewajiban perpajakannya.

Hipotesis ini menguji secara bersama (simultan) variabelPenerapan e-Filling $\left(\mathrm{X}_{1}\right)$ dan Sanksi Pajak $\left(\mathrm{X}_{2}\right)$. Dalam melakukan analisis dengan dua variable independent ini diperlukan untuk mengetahui pengaruh kedua variable independent secara bersamasama terhadap veriabel dependen.

$\mathrm{H}_{3}$ : Penerapan e-Filling dan Sanksi Pajak secara bersama - sama diduga berpengaruh positif terhadap Kepatuhan Wajib Pajak Orang Pribadi dalam Melaporkan Pajak.

Normative beliefs menyatakan bahwa ketika akan melakukan sesuatu individu akan memiliki keyakinan tentang harapan normatif dari orang lain dan motivasi untuk memenuhi harapan tersebut. Dalam hal ini whistleblowing system adalah faktor yang dapat mendorong dan memotivasi wajib pajak dalam meningkatkan kepatuhan perpajakannya. Dalam hal ini wajib pajak akan sadar jika dalam penyampaian kewajiban perpajakannya harus dilakukan dengan tepat sesuai dengan peraturan perundang-undangn baik waktu 
penyampaian ataupun perhitungan sehingga tidak ada resiko yang akan di alami oleh wajib pajak.

Menurut Erawati, dan Ratnasari, (2018), e-Filling berpengaruh positif terhadap kepatuhan wajib pajak dalam menyampaikan SPT. Jika wajib pajak dalam menyampaikan SPT diberikan kemudahan, kenyamanan dan keamanan dari program e-filling maka wajib pajak akan patuh dalam melakukan penyampaian SPT. Agustiningsih \& Isroah, (2016) menyatakan bahwa penerapan efilling berpengaruh positif terhadap Kepatuhan Wajib Pajak di KPP Pratama Yogyakarta.

Whistleblowing system menurut PMK nomor 103/PMK.09/2010 adalah suatu aplikasi yang disediakan oleh kementerian keuangan bagi pegawai yang memiliki informasi dan ingin melaporkan suatu perbuatan berindikasi pelanggaran yang terjadi di lingkungan Kementerian Keuangan Republik Indonesia.

Suyadi dan Sunarti, (2016) dan Siringoringo, (2015) menyatakan whistleblowing system berpengaruh positif terhadap kepatuhan wajib pajak. Dengan adanya e-filling maka wajib pajak semakin dipermudah dalam melaporkan pajak dan dengan adanya whistleblowing system maka wajib pajak akan semakin taat dalam melaporkan pajak dikarenakan adanya motivasi yang lebih kuat untuk wajib pajak dalam menyampaikan SPT.

$\mathrm{H}_{4}$ : Whistleblowing System diduga memperkuat pengaruh Penerapan eFilling terhadap Kepatuhan Wajib Pajak Orang Pribadi dalam Melaporkan Pajak.

Sanksi Pajak merupakan pemberian sanksi bagi wajib pajak yang tidak memenuhi kewajibannya sesuai dengan peraturan perundang-undangan yang berlaku. Wajib pajak akan memenuhi kewajiban perpajakan dengan memandang bahwa sanksi perpajakan akan lebih banyak merugikan (Kodoati et al., 2016)

Whistleblowing system yang efektif, transparan dan bertanggung jawab dapat mengurangi risiko yang dihadapi organisasi, akibat dari adaya pelanggaran pajak baik dari segi keuangan, operasi, hukum, keselamatan kerja, dan reputasi dari organisasi tersebut (Suyadi \& Sunarti, 2016). Jika dinilai dari risiko yang akan terjadi maka dengan adanya sanksi pajak yang didukung dengan whistleblowing system diharapkan wajib pajak semakin taat dalam hal pelaporan perpajakan.

$\mathrm{H}_{5}$ : Whistleblowing System diduga memperkuat pengaruh Sanksi Pajak terhadap Kepatuhan Wajib Pajak Orang Pribadi dalam Melaporkan Pajak.

Jika digambarkan, maka kerangka berpikir yang dapat disimpulkan dari 
hipotesis-hipotesis tersebut, adalah sebagai berikut:

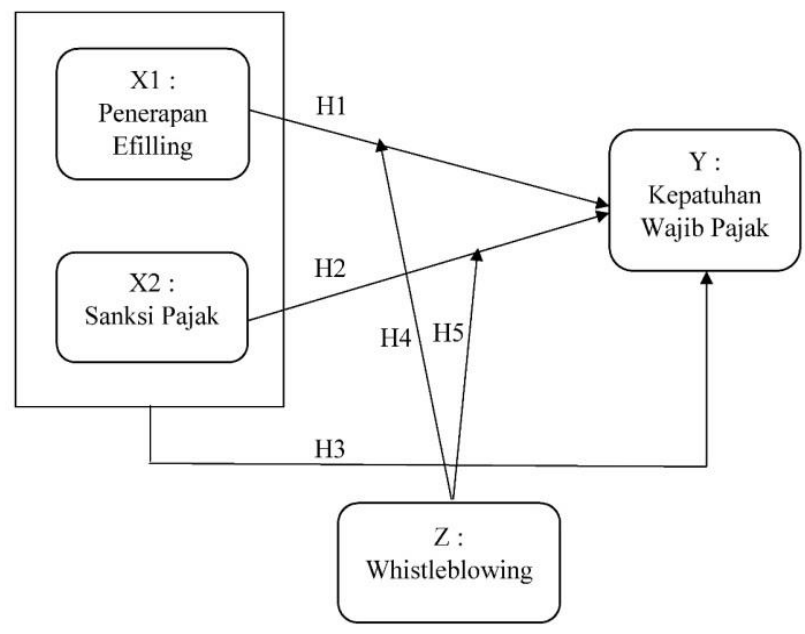

Gambar 1: Kerangka Berfikir

\section{METODE PENELITIAN}

\section{Jenis Penelitian}

Penelitian ini merupakan penelitian kuantitatif, yang bertujuan untuk mengetahui hubungan serta pengaruh dari variabel independen yaitu penerapan e-filling (X1), dan sanksi pajak (X2) terhadap variabel dependen yaitu kepatuhan wajib pajak (Y), dengan menggunakan variabel moderating yaitu whistleblowing $(Z)$.

Metode penelitian kuantitatif dapat diartikan sebagai metode penelitian yang berlandaskan pada filsafat positivisme, digunakan untuk memenuhi populasi atau sampel tertentu, pengumpulan data menggunakan instrumen penelitian, analisis data bersifat kuantitatif atau statistik, dengan tujuan untuk menguji hipotesis yang telah ditetapkan. Penelitan kuantitatif pada umumnya dilakukan pada sampel yang diambil secara random, sehingga hasil penelitian dapat digeneralisasikan pada populasi dimana sampel tersebut diambil (Sugiyono, 2016).

Jenis data yang digunakan dalam penelitian ini adalah data primer. Data primer merupakan data yang hanya dapat diperoleh dari sumber asli atau pertama. Data primer harus secara langsung kita ambil dari sumber aslinya, melalui narasumber yang tepat dan yang kita jadikan responden dalam penelitian. Data primer diperoleh dari kuesioner yang berasal dari wajib pajak orang pribadi (OP) yang terdaftar di Kantor Pelayanan Pajak (KPP) Pratama Serpong.

\section{Tempat dan Waktu Penelitian}

Adapun lokasi penelitian ini dilakukan pada Kantor Pelayanan Pajak Pratama Serpong yang berada di Jalan Raya Serpong Sektor VIII, J1. Komp. BSD No. 4, Lengkong Gudang, Kec. Serpong, Tangerang, Banten 1532. Pada penelitian ini peneliti hanya mengambil Wajib Pajak Orang Pribadi yang terdaftar pada wilayah KPP Pratama Serpong. Penelitian dilakukan pada bulan November - Desember 2019

\section{Subjek Penelitian}

Populasi dalam penelitian ini adalah Wajib Pajak Orang Pribadi yang sudah menggunakan E-Filling dan terdaftar di KPP Pratama Serpong sebanyak 58.000 orang. Teknik pengambilan sampel menggunakan 


\section{Nominal: Barometer Riset Akuntansi dan Manajemen \\ P-ISSN: 2303-2065 E-ISSN: 2502-5430 \\ Volume 9 No 2 (2020)}

convenience sampling dan rumus slovin dengan tingkat kesalahan pada penilitian social maksimal $10 \%$ atau 0,01 . Dan didapatkan sampel sebanyak 108 responden.

\section{Prosedur}

Metode pengumpulan data yang digunakan adalah data primer yang berisi pertanyaan-pertanyaan yang ditunjukkan kepada responden.

\section{Data, Instrumen, dan Teknik Pengumpulan Data}

Data yang digunakan dalam penelitian ini adalah data primer. Teknik yang digunakan untuk mengumpulkan data pada penelitian ini menggunakan kuesioner.

Instrumen penelitian yang digunakan dalam penelitian ini berupa angket tertutup, responden hanya memberikan checklist $(\sqrt{ })$ pada alternatif jawaban yang telah disediakan. Responden diminta melakukan penilaian berupa angka tentang Peran Whistle Blowing System Dalam Memoderasi Penerapan E-Filling Dan Sanksi Perpajakan Terhadap Kepatuhan Wajib Pajak di KPP Pratama Serpong.

Indikator yang digunakan untuk mengukur variabel penerapan e-filling diadopsi dan dimodifikasi dari Hendri, (2019) yaitu; kecepatan pelaporan, kemudahan, kelengkapan, praktis dan ramah lingkungan. Variabel penerapan sanksi pajak dan kepatuhan wajib pajak diadopsi dan dimodifikasi dari (Putri \& Putri, 2019) yaitu; menciptakan kedisiplinan, tentangan, keberatan dan ketegasan sanksi pajak serta kepatuhan dalam mendaftarkan, melaporkan, menghitung dan membayar tunggakan pajak. Sedangkan variabel penerapan whistleblowing diadopsi dan dimodifikasi dari Siringoringo, (2015) yaitu; menggunakan whistleblowing sesuai fungsi, kemudahan, confidential, melaporkan ketidakwajaran, penanganan tindak kecurangan dan melaporkan dengan bukti yang akurat.

\section{Teknik Analisis Data}

Uji validitas dan uji reliabilitas dalam penelitian ini dilakukan pada sampel berjumlah 108 responden dari total sampel penelitian yang digunakan. Uji validitas dengan menggunakan korelasi Pearson Product Moment dan uji reliabilitas menggunakan Cronbach Alpha. Sedangkan hipotesis penelitian diolah menggunakan alat analisis regresi linear sederhana dan berganda untuk mengetahui pengaruh Penerapan E-Filling Dan Sanksi Perpajakan secara parsial maupun secara bersama-sama terhadap Kepatuhan Wajib Pajak di KPP Pratama Serpong. Selain itu juga menggunakan Moderated Regression Analysis (MRA). 


\section{HASIL PENELITIAN DAN \\ PEMBAHASAN}

\section{Hasil}

Hasil Uji Regresi Linear Sederhana untuk setiap hipotesis adalah:

Tabel 1: Hasil Regresi Linear Sederhana $\mathrm{H}_{1}$

\begin{tabular}{cccc}
\hline $\begin{array}{c}\text { Unstandarized } \\
\text { coefficient }\end{array}$ & T & Sig & Informasi \\
\hline 0,506 & 4,149 & 0,000 & $\begin{array}{l}\text { Hipotesis } \\
\text { Pertama } \\
\text { Diterima }\end{array}$ \\
\hline
\end{tabular}

Sumber: Data primer yang diolah, 2019

Berdasarkan tabel di atas, dapat dilihat bahwa nilai thitung adalah sebesar 4,149 jika dibandingkan dengan tabel pada tingkat signifikansi 0,01 atau $1 \%$, yaitu sebesar 1,982; maka thitung lebih besar daripada tabel $(4,149>1,982)$. Nilai signifikansi sebesar 0,000 menunjukkan nilai yang lebih kecil dibandingkan dengan nilai pada tingkat signifikansi yang telah ditentukan sebelumnya, yaitu $0,01(0,000<0,01)$.

Hal ini berarti penerapan e-filing secara parsial berpengaruh positif dan signifikan terhadap kepatuhan wajib pajak.

Tabel 2. Hasil Regresi Linear Sederhana $\mathrm{H}_{2}$

\begin{tabular}{cccc}
\hline $\begin{array}{c}\text { Unstandarized } \\
\text { coefficient }\end{array}$ & T & Sig & Informasi \\
\hline 0,515 & 3,316 & 0,001 & $\begin{array}{c}\text { Hipotesis } \\
\text { Kedua } \\
\text { Diterima }\end{array}$ \\
\hline
\end{tabular}

Sumber: Data primer yang diolah, 2019

Berdasarkan tabel di atas, dapat dilihat bahwa nilai thitung adalah sebesar 3,316 jika dibandingkan dengan tabel pada tingkat signifikansi 0,01 atau $1 \%$, yaitu sebesar
1,982; maka thitung lebih besar daripada tabel $(3,316>1,982)$. Nilai signifikansi sebesar 0,001 menunjukkan nilai yang lebih kecil dibandingkan dengan nilai pada tingkat signifikansi yang telah ditentukan sebelumnya, yaitu $0,01(0,001<0,01)$.

Hal ini berarti bahwa sanksi perpajakan secara parsial berpengaruh positif dan signifikan terhadap kepatuhan wajib pajak.

Tabel 3. Hasil Regresi Linear Berganda $\mathrm{H}_{3}$

\begin{tabular}{ccc}
\hline $\mathbf{F}$ & Sig & Informasi \\
\hline 16.625 & 0,000 & $\begin{array}{c}\text { Hipotesis Ketiga } \\
\text { Diterima }\end{array}$ \\
\hline
\end{tabular}

Sumber: Data primer yang diolah, 2019

Dari hasil pengujian diperoleh nilai Fhitung sebesar 16,625 lebih besar dari $\mathrm{F}_{\text {tabel }}$ sebesar 3,08 dengan signifikansi sebesar 0,000. Oleh karena nilai $F_{\text {hitung }}>F_{\text {tabel }}(16,625>3,08)$ dan signifikansi lebih kecil dari 0,01 $(0,000<0,01)$, maka dapat disimpulkan bahwa hipotesis ketiga yang menyatakan "Penerapan E-Filling Dan Sanksi Perpajakan berpengaruh positif terhadap terhadap Kepatuhan Wajib Pajak di KPP Pratama Serpong" terbukti.

Tabel 4. Hasil Analisis MRA X

\begin{tabular}{cccc}
\hline Variable & T & Sig & Informasi \\
\hline $\mathrm{X}_{1} \mathrm{Z} \mathrm{Z}$ & 7,553 & 0,000 & $\begin{array}{c}\text { Hipotesis } \\
\text { Keempat } \\
\text { Diterima }\end{array}$ \\
\hline
\end{tabular}

Sumber: Data primer yang diolah, 2019

Pada tabel 4 menunjukan variabel $\mathrm{X}_{1} * \mathrm{Z}$ (interaksi antara variabel penerapan e-filling dengan whistleblowing system) mempunyai 
nilai thitung sebesar 7,553 lebih besar dari tabel 1,982 dengan signifikansi 0,000 . Hal ini berarti bahwa variabel whistleblowing memoderasi hubungan antara penerapan $e$ filling terhadap kepatuhan wajib pajak.

Tabel 5. Hasil Analisis MRA $\mathrm{X}_{2}$

\begin{tabular}{cccc}
\hline Variable & $\mathbf{T}$ & Sig & Informasi \\
\hline $\mathrm{X}_{2} \mathrm{Z}$ & 7,907 & 0,000 & $\begin{array}{c}\text { Hipotesis } \\
\text { Kelima } \\
\text { Diterima }\end{array}$ \\
\hline
\end{tabular}

Sumber : Data primer yang diolah, 2019

Pada tabel 5 menunjukan variabel $\mathrm{X}_{2} * \mathrm{Z}$ (interaksi antara variabel sanksi perpajakan dengan whistleblowing system) mempunyai nilai thitung sebesar 7,907 lebih besar dari tabel 1,982 dengan signifikansi 0,000. Hal ini berarti bahwa variabel whistleblowing memoderasi hubungan antara sanksi perpajakan terhadap kepatuhan wajib pajak.

\section{Pembahasan}

1. Penerapan E-Filling berpengaruh positif terhadap Kepatuhan Wajib Pajak Orang Pribadi dalam

\section{Melaporkan Pajak.}

Hasil uji hipotesis 1 ditunjukan pada tabel 1 dimana nilai thitung pada variabel penerapan e-filling $\left(\mathrm{X}_{1}\right)$ adalah 4,149 dengan tingkat signifikansi 0,000. Oleh karena itu, hipotesis $\mathrm{H}_{1}$ dalam penelitian ini diterima. Sehingga dapat dikatakan bahwa penerapan e-filling berpengaruh signifikan terhadap kepatuhan wajib pajak karena tingkat signifikansinya lebih kecil dari 0,01.
Hasil ini sesuai dengan penelitian yang dilakukan oleh Agustiningsih dan Isroah, (2016), dan Jayanti, (2017) yang menyatakan bahwa penerapa e-filling berpengaruh signifikan terhadap kepatuhan wajib pajak.

Kesimpulannya dengan adanya sistem efilling maka Wajib Pajak akan semakin dipermudah dalam melaporkan pajaknya sehingga tingkat kepatuhannya akan semakin meningkat.

2. Sanksi Pajak berpengaruh positif terhadap Kepatuhan Wajib Pajak

Orang Pribadi dalam Melaporkan

\section{Pajak.}

Hasil uji hipotesis 2 yang ditunjukan pada tabel 2 nilai thitung pada variabel sanksi perpajakan $\left(\mathrm{X}_{2}\right)$ adalah 3,316 dengan tingkat signifikansi 0,001. Oleh karena itu, hipotesis $\mathrm{H}_{2}$ dalam penelitian ini diterima. Sehingga dapat dikatakan bahwa sanksi perpajakan berpengaruh signifikan terhadap kepatuhan wajib pajak karena tingkat signifikansinya lebih kecil dari 0,01.

Hasil penelitian ini memperkuat penelitian dari Cahyani dan Noviari, (2019) dan Suyadi dan Sunarti, (2016) yang menyatakan bahwa sanksi perpajakan berpengaruh dan signifikan terhadap kepatuhan wajib pajak.

Hasil ini disimpulkan bahwa dengan diterapkannya sanksi perpajakan maka akan semakin meningkatkan kepatuhan wajib pajak dikarenakan wajib pajak akan lebih 
Nominal: Barometer Riset Akuntansi dan Manajemen

P-ISSN: 2303-2065 E-ISSN: 2502-5430

Volume 9 No 2 (2020)

banyak mengeluarkan uang untuk membayar pajak.

\section{Penerapan e-Filling dan Sanksi Pajak} secara bersama - sama berpengaruh positif terhadap Kepatuhan Wajib Pajak Orang Pribadi dalam Melaporkan Pajak.

Hasil uji hipotesis 3 yang ditunjukan pada tabel 3 nilai $F_{\text {hitung }}$ pada variabel penerapan dan sanksi perpajakan adalah sebesar 16,625 dengan tingkat signifikansi 0,000 atau lebih kecil dari 0,01. Oleh karena itu hipotesis $\mathrm{H}_{3}$ dalam penelitian ini diterima. Maka dapat diketahui variabel penerapan e-filling dan sanksi pajak berpengaruh signifikan secara simultan atau bersama-sama terhadap kepatuhan wajib pajak.

Penelitian ini mendukung penelitian yang dilakukan oleh Hartanti dan Husein, (2018) yang menjelaskan bahwa penerapan e-filling dan sanksi pajak berpengaruh positif terhadap kepatuhan wajib pajak.

Hal ini menunjukan apabila Wajib Pajak dipermudah dengan adanya e-filling dan ditambah dengan adanya sanksi pajak yang berlaku maka akan semakin meningkatkan kepatuhan wajib pajak dalam melaporkan pajaknya.

\section{Whistleblowing System memperkuat} pengaruh $e$-Filling terhadap
Kepatuhan Wajib Pajak Orang Pribadi dalam Melaporkan Pajak.

Hasil uji hipotesis 4 yang ditunjukan pada tabel 4 nilai thitung pada variabel penerapan e-filling yang dimoderasi oleh whistleblowing adalah sebesar 7,553 dengan tingkat signifikansi 0,000 . Hal ini berarti whistleblowing memperkuat hubungan antara penerapan e-filling terhadap kepatuhan wajib pajak, oleh karena itu $\mathrm{H}_{4}$ dalam penelitian ini diterima.

Maka dapat disimpulkan bahwa dengan adanya sistem e-filling yang sangkat mempermudah wajib pajak dalam melaporkan pajaknya dengan diperkuat adanya whistleblowing system yang efektif, transparan dan bertanggung jawab yang dapat mengurangi resiko yang harus dihadapi wajib pajak akibat dari adanya pelanggaran pajak maka wajib pajak akan semakin meningkatkan kepatuhan wajib pajak dalam melaporkan pajaknya.

5. Whistleblowing System memperkuat pengaruh Sanksi Pajak terhadap Kepatuhan Wajib Pajak Orang Pribadi dalam Melaporkan Pajak.

Hasil uji hipotesis 5 yang ditunjukan pada tabel 5 nilai thitung pada variabel sanksi perpajakan yang dimoderasi oleh whistleblowing adalah sebesar 7,907 dengan tingkat signifikansi 0,000 . Hal ini berarti whistleblowing memperkuat hubungan antara sanksi perpajakan terhadap kepatuhan 
wajib pajak, oleh karena itu $\mathrm{H}_{5}$ dalam penelitian ini diterima.

Maka dapat disimpulkan bahwa adanya sanksi pajak wajib pajak akan memenuhi kewajiban perpajakan karena memandang bahwa sanksi perpajakan akan lebih banyak merugikan diperkuat dengan adanya whistleblowing system yang mempunyai resiko akibat adanya pelanggaran pajak baik dari segi keuangan, hukum dan reputasi maka mendorong wajib pajak untuk memenuhi kewajiban perpajakannya.

\section{SIMPULAN DAN SARAN}

\section{Simpulan}

Hasil penelitian ini menunjukkan bahwa penerapan $e$-filing, dan sanksi perpajakan berpengaruh positif dan signifikan terhadap kepatuhan wajib pajak, baik secara partial maupun simultan. Sedangkan Whistle Blowing mampu memoderasi pengaruh penerapan e-filing dan sanksi perpajakan terhadap kepatuhan wajib pajak.

\section{Saran}

Peneliti selanjutnya agar dapat lebih mengembangkan penelitian ini dengan meneliti faktor lain yang dapat mempengaruhi kepatuhan wajib pajak pada KPP Pratama Serpong. Misalnya dengan menambahkan variable sikap atau pelayanan fiskus, sikap rasional dan kesadaran wajib pajak. Sehingga akan semakin mendalam lagi jika ada faktor lain yang dapat memengaruhi kepatuhan wajib pajak pada KPP Pratama Serpong.

Untuk KPP Pratama dan DJP diharapkan dapat memberikan pengetahuan tambahan atau mengadakan seminar perpajakan tentang whistle blowing system guna menambah wawasan wajib pajak sehingga wajib pajak mengetahui pentingnya penerapan whistle blowing system.

\section{DAFTAR PUSTAKA}

Agustiningsih, W., \& Isroah, I. (2016). Pengaruh Penerapan E-Filing, Tingkat Pemahaman Perpajakan Dan Kesadaran Wajib Pajak Terhadap Kepatuhan Wajib Pajak Di Kpp Pratama Yogyakarta. Nominal, Barometer Riset Akuntansi Dan Manajemen. https://doi.org/10.21831/nominal.v5i2. 11729

Cahyani, L. P. G., \& Noviari, N. (2019). Pengaruh Tarif Pajak, Pemahaman Perpajakan, dan Sanksi Perpajakan Terhadap Kepatuhan Wajib Pajak UMKM. E-Jurnal Akuntansi. https://doi.org/10.24843/eja.2019.v26.i 03.p08

Erawati, T. \& Ratnasari, R. (2018). Pengaruh Penerapan E-Filling terhadap Kepatuhan (Studi Empiris Di Kabupaten Gunungkidul). Jurnal Akuntansi.

Hartanti, E., \& Husein, S. (2018). Pengaruh Penerapan Sistem e-Filing , Pengetahuan Pajak, dan Sanksi Pajak Terhadap Kepatuhan Wajib Pajak Orang Pribadi. Issn 2356 - 4385.

Hendri. (2019). E-Filling, Pemahaman, Sanksi Perpajakan, Biaya Kepatuhan, dan KepuasanKualitas Pelayanan terhadap Kepatuhan Pelaporan SPT 
Tahunan WP OP. Jaaf, 3(2), 150-162.

Jayanti, E. D. (2017). Penggaruh Penerapan Sistem E-Filing, Pemahaman Perpajakan dan Kesadaran Wajib Pajak Terhadap Kepatuhan Wajib Pajak. EPrint STIE Perbanas.

Kodoati, A., J. Sondakh, J., \& Ilat, V. (2016). Pengaruh Sikap Wajib Pajak Pada Pelaksanaan Sanksi Denda, Pelayanan Fiskus Dan Kesadaran Perpajakan Terhadap Kepatuhan Wajib Pajak (Studi Empiris Terhadap Wajib Pajak Restoran Orang Pribadi Di Kota Manado Dan Di Kabupaten Minahasa). Accountability, $\quad 5(2), \quad 1$. https://doi.org/10.32400/ja.14420.5.2.2 016.1-10

Mangoting, Y., \& Jotopurnomo, C. (2013). Pengaruh Kesadaran wajib Pajak, Kualitas Pelayanan fiskus, Sanksi perpajakan, Lingkungan Wajib Pajak berada terhadap Kepatuhan Wajib Pajak Orang Pribadi di Surabaya. Tax \& Accounting Review.

Mardiasmo. (2018). Perpajakan Edisi Terbaru 2018. In Penerbit ANDI.

Ngadiman, N., \& Huslin, D. (2017). Pengaruh Sunset Policy, Tax Amnesty, Dan Sanksi Pajak Terhadap Kepatuhan Wajib Pajak (Studi Empiris di Kantor Pelayanan Pajak Pratama Jakarta Kembangan). Jurnal Akuntansi. https://doi.org/10.24912/ja.v19i2.96

Ningsih, H. T. K., \& Rahayu, S. (2013). Pengaruh Kemanfaatan NPWP, Pemahaman Wajib Pajak, Kualitas Pelayanan, Sanksi Perpajakan Terhadap Kepatuhan Wajib Pajak di KPP Pratama Medan Kota. Journal of Accounting and Economics, 2(2009), 1-15.

Putri, N. E., \& Putri, T. C. (2019). Keterkaitan penerapan sistem e-filing, sosialisasi perpajakan dan kepatuhan wajib pajak orang pribadi pada kpp pratama kebayoran baru iii. 2(2), 95104.

Sari, R. R., \& Erawati, T. (2018). pengaruh penerapan efiling terhadap kepatuhan wajib pajak dalam menyampaikan SPT tahunan dengan kepuasan kualitas pelayanan sebagai variabel intervening. Jurnal Akuntansi. https://doi.org/10.24964/ja.v6i1.427

Siamena, E., Sabijono, H., \& Warongan, J. D. . (2017). Pengaruh Sanksi Perpajakan Dan Kesadaran Wajib Pajak Terhadap Kepatuhan Wajib Pajak Orang Pribadi Di Manado. Going Concern: Jurnal Riset Akuntansi. https://doi.org/10.32400/gc.12.2.18367. 2017

Siringoringo, W. (2015). Pengaruh Penerapan Good Governance Dan Whistleblowing System Terhadap Kepatuhan Wajib Sebagai Variabel Moderating ( Studi Empiris Terhadap Wajib Pajak Orang Pribadi Di Kota Bekasi ) Whereson Siringoringo. Jurnal Akuntansi.

Sugiyono (2016), Metode penelitian kuantitatif, kualitatif,dan R\&D, Alfabeta, Bandung

Suyadi, I., \& Sunarti. (2016). Pengaruh Sosialisasi Perpajakan, Sanksi Administrasi dan Tingkat Pemahaman Wajib Pajak terhadap Kepatuhan Wajib Pajak Orang Pribadi dalam Memenuhi Kewajibannya (Studi PPh Pasal 21 pada KPP Pratama Singsosari). Jurnal Perpajakan.

https://doi.org/10.1017/CBO97811074 15324.004 